\title{
TREASURY SINGLE ACCOUNT (TSA) AND PERFORMANCE OF PUBLIC SECTOR IN ENUGU STATE, NIGERIA
}

\author{
Chinomso Chioms Okorocha \\ Public Administration/Faculty of Management and Social Sciences/Godfrey Okoye \\ University Enugu, Nigeria.
}

Email: chinomsoonyeaso@gmail.com

Cite this article:

Chinomso Chioms Okorocha (2022), Treasury Single Account (TSA) and Performance of Public Sector in Enugu State, Nigeria. British Journal of Management and Marketing Studies 5(1), 79-92. DOI: 10.52589/BJMMSQDL7GMUV

\section{Manuscript History}

Received: 16 Jan 2022

Accepted: 5 Jan 2022

Published: 22 Feb 2022

Copyright $\odot 2022$ The Author(s). This is an Open Access article distributed under the terms of Creative Commons AttributionNonCommercial-NoDerivatives 4.0 International (CC BY-NC-ND 4.0), which permits anyone to share, use, reproduce and redistribute in any medium, provided the original author and source are credited.

\begin{abstract}
The importance of the introduction of treasury single account cannot be overemphasized given that it is principally to ensure accountability of government revenue, enhance transparency and avoid expropriation of public funds. This study examined the effect of treasury single account on the performance of selected Federal Ministries in Enugu State. The study adopted survey research design. The method ensured that the researcher collects his data at a particular period from the selected sample to describe a large population at that particular point in time. The study area of this research is selected federal ministries namely Ministry of Agriculture and Ministry of Education all located in Enugu state. The population of the study constitutes of the staff of two selected federal ministries in Enugu state namely; Federal Ministry of Agriculture and Federal Ministry of Education. The population of the two selected ministries is totaled two hundred and eighty-seven (287) staff. The sample size was derived using the Cochran statistic and the value derived was three hundred and eighty-five (385). To determine the number of staff to be selected from each ministry, the proportionate stratified random sampling approach was used. The data was collected with the aid of a questionnaire that is properly drafted using the 5 scale Likert system for questionnaire. The Cronbach Alpha reliability test was utilized to conduct the reliability test. A cronbach alpha coefficient of 0.78 was derived and was considered acceptable. Frequency tables and percentages was adopted to analyse the demographic characteristics of the respondents and leading research questions while the regression analysis was adopted to test the hypotheses of the study. The major findings of the study were that treasury single account has not significantly ameliorated fund misappropriation in selected federal ministries in Enugu State and treasury single account has not significantly enhanced prompt release of funds for goods and services in selected federal ministries in Enugu State. It is therefore the recommendation of the study that the adoption of TSA alone may not be sufficient to curb corruption in the Nigerian public sector hence the need for the judiciary, police, anti-graft agencies and the media in the country be strengthened to tackle the issues of corruption and ensure transparency, probity and timeliness in handling corruption related cases.
\end{abstract}

KEYWORDS: Treasury Single Account, Public Sector, Accountability, Nigeria 


\section{INTRODUCTION}

Any economy's economic, political, and social success is based on the concept of accountability, which is a derivative of the word 'account.' If the notion of accountability is facilitated in the system, any economy's government would work better and more efficiently. The notion of a treasury single account (TSA) was introduced into Nigeria's banking system under this framework. Government Ministries, Departments, and Agencies (MDAs) generated revenue but had multiple accounts in deposit money banks from which they (MDAs) used part of the revenue to fund their operations and remitted the surplus to the federation account until the introduction of Treasury Single Account (TSA) in Nigeria in 2012. This model created a system of operations that caused the federal government of Nigeria to lose a large amount of money meant for key sector development to pay salaries and operational costs, as most ministries, departments, and agencies that should generate large amounts of money declare deficits at the end of each fiscal year. As a result of this enormous problem, the government devised an accounting system known as the Treasury Single Account (TSA), which is designed to promote accountability in the collecting of government revenue, increase transparency, and decrease expropriation of such funds by government agencies (Anderson, 2016).

The purpose of the treasury single account is to ensure government revenue accountability, transparency, and avoid the expropriation of public monies. The treasury single account, which will be kept at Nigeria's central bank (CBN), will bring together government policies for improved cash management and the most efficient use of public monies (Boulder, 2015). Prior to the advent of TSA, agencies paid into the government account whatever they saw fit, resulting in government underpayment. The importance of any administration adopting and fully implementing the Treasury Single Account (TSA), especially in a down economy, cannot be overstated because it promotes openness and accountability in government parastatals (Anayo, 2017).

The adoption of a treasury single account is also expected to improve public sector performance, particularly in terms of service delivery and productivity. Despite the advent of TSA in Nigeria, there are still examples of corruption in the Nigerian public sector. Babachir Lawal, the then-Secretary to the Federal Government of Nigeria, was indicted in a N200 million contract controversy in 2016 for eradicating invasive plant species in IDP camps in Yobe State, Nigeria's North-Eastern state. Mustapha Maihaja, the Director-General of Nigeria's National Emergency Management Agency (NEMA), was indicted in 2018 for mismanaging a N5.8 billion intervention fund allocated for interventions in the country's northeastern region (Stober 2019).

Although the majority of these cases were investigated and appropriate actions were taken, the fact that they arose in the first place indicates that the Nigerian public sector is still plagued by issues of accountability, fund misappropriation, and corruption, which has influenced public perceptions of the effectiveness of government anti-corruption strategies. TSA, as one of the most visible ways to combat mismanagement of funds and corruption in the Nigerian public sector, would have effectively alleviated some of the corruption concerns that arose. As a result, the fact that these cases have surfaced has cast doubt on TSA's efficiency in combating corruption in Nigeria. 


\section{REVIEW OF LITERATURE}

The effect of treasury single account (TSA) on corruption in the Nigerian public sector was investigated by John et al, (2021). This study was prompted by the extent to which TSA has influenced Nigeria's Corruption Perception Index (CPI). Transparency International provided data from 2012 to 2014 (before TSA adoption) and 2016 to 2018 (after TSA adoption), with 2015 serving as the base year. Descriptive statistics and paired samples t-test statistics were used to assess the data. According to the findings of the study, there is no significant difference in the mean of the corruption perception index (CPI) in Nigeria before and after TSA introduction. TSA has not considerably decreased corruption in the Nigerian public sector, according to the report. According to the report, the Federal government should improve the country's court, police, anti-graft agencies, and media in order to combat corruption and ensure openness, probity, and timeliness in dealing with corruption-related matters.

Benjamin, Adamna, and Jane (2020) investigated the impact of the Treasury Single Account (TSA) on the financial performance of Nigerian commercial banks. The study used an expofacto survey research design and seven major Nigerian commercial banks. For this study, judgment samples were taken from First Bank of Nigeria, Zenith Bank, Access Bank, UBA, Union Bank, Diamond Bank, and Fidelity Bank. From 2013 to 2017, secondary data was acquired through the CBN statistical bulletin (that is two years before and two years after the implementation of TSA). Customers' deposits (Treasury Single Account) were utilized as proxies for the independent variable, whereas profit after tax, return on equity, and return on assets were used as proxies for the dependent variable (financial performance). Simple regression analysis was used to evaluate study hypotheses, while a similar mean was used to assess the data acquired. Customers' deposits have a considerable impact on profit after tax, return on assets, and return on equity of commercial banks in Nigeria, according to the results of statistical testing of the study's assumptions.

Allison and Ndukwe (2021) evaluated the extent to which the Treasury Single Account's implementation in Nigeria has aided in the achievement of public accountability in Nigeria's governmental sectors. As a method of data collection and analysis, the paper used content analysis. The Treasury Single Account has enthroned centralized, transparent, and accountable revenue management in Nigeria, according to the study, by imposing fiscal discipline and maintaining effective aggregate control over government cash balances. The study argued that strengthening and maintaining the Treasury Single Account (TSA) scheme is the only solution for Nigeria to combat the tremendous pressure on its cash flows in the face of falling revenues and decreasing statutory and social duties.

In Ondo State, Nigeria, Lodikero, Fagbayimu, and Olateru (2018) investigated Treasury Single Account: A Tool for Accountability and Transparency. In order to ensure a responsible governance system, the study looked at the impact of the Treasury Single Account on the accountability and openness of the Nigerian public sector. The study was conducted using a survey research design. As of 2017, the study's population included 150 Ministries, Departments, and Agencies (MDAs) working in Ondo State. The respondents were chosen using a process known as purposeful sampling. The descriptive and inferential statistical tools were used to evaluate the data received from the questionnaire administration. According to the findings, the Treasury Single Account is an effective tool for controlling financial leakages in the Nigerian government. 
Solanke (2018) looked at the public's view and perceptions of the Treasury Single Account's implementation in Nigeria for revenue production and utilization. The study relied on primary data. A total sample size of 200 people was purposefully chosen. Frequency and percentages, as well as an analytic weighted mean, were used to examine the data. The findings revealed a range of attitudes on TSA implementation in Nigeria.

\section{METHODOLOGY}

The study used a survey research approach. The strategy assured that the researcher gets data from a selected sample at a specific time in order to describe a vast population at that time. Because the method allowed the researcher to use the sample drawn to represent the varied elements of the population under investigation, it was chosen.

\section{Population of the Study}

The population of the study constitutes the staff of two selected federal ministries in Enugu state namely; the Federal Ministry of Agriculture and the Federal Ministry of Education. The population of the two selected ministries is totalled two hundred and eighty-seven (287) persons. The population distribution is shown in table 1 below.

\section{Table 1: Population of the Study}

\begin{tabular}{|l|l|}
\hline Industry & Number of Staff \\
\hline Federal Ministry of Agriculture & 89 \\
\hline Federal Ministry of Education & 198 \\
\hline Grand Total & $\mathbf{2 8 7}$ \\
\hline
\end{tabular}

Source: Field Survey, 2022.

\section{Sample Size Determination}

For this research, the sample size was derived using Cochran's (1963:75) sample size formula.

This is given as:

$$
n=\frac{n_{0}}{1+\frac{\left(n_{0}-1\right)}{N}}
$$

Where:

$\mathrm{n}_{\mathrm{o}}=$ Representative sample for proportions

$\mathrm{n}=$ Sample Size

$\mathrm{N}=$ Population Size

$\mathrm{e}=$ Allowable sampling error taken at $5 \%=0.05$

$p=$ Proportion of success in the population from pilot survey $=0.50$

$q=$ proportion of failure in the population from pilot survey $=0.50$ 
However:

$n_{0}=\frac{Z^{2} p q}{e^{2}}$

Where; $\mathrm{Z}^{2}$ is the abscissa of the normal curve (1.96), $\mathrm{q}$ is $1-\mathrm{p}$ and e is the allowable sample error (0.05). Substituting these values into equation 3.2, we have:

$n_{0}=\frac{Z^{2} p q}{e^{2}}=\frac{(1.96)^{2}(0.5)(0.5)}{(0.05)^{2}}=385$

Substituting $\mathrm{n}_{\mathrm{o}}=385$ from equation 3.3 into equation 3.1, we have:

$$
\begin{aligned}
& n=\frac{385}{1+\frac{(385-1)}{287}} \\
& n=\frac{385}{1+1.3379790941} \\
& n=\frac{385}{2.3379790941}=164
\end{aligned}
$$

Having applied the Cochran sample size derivation statistic, the value derived was one hundred and sixty-four (164). Hence; the sample size for this study is one hundred and sixty-four respondents.

\section{Method of Data Analysis}

Frequency tables and percentages were adopted to analyse the demographic characteristics of the respondents and leading research questions while the regression analysis was adopted to test the hypotheses of the study.

\section{Software for Data Analysis}

The software used in this study is the Statistical Package for Social Sciences (SPSS) version 23.

\section{RESULTS AND ANALYSIS}

In this part of the research, information generated through the distribution of well-structured questionnaires were analysed using the tabled frequencies and corresponding percentages of the demographic characteristics of the respondents. The hypotheses of the study were tested using the Ordinary Least Squares (OLS) technique with the application of regression analysis. The statistical software employed is the statistical package for social sciences (SPSS) 


\section{Questionnaire Return Rate}

In the course of the study, questionnaires were distributed to the various sampled federal ministries in Enugu state; and given the uncertainties beclouding survey studies, not all questionnaires distributed were returned and properly filled. This section of the study displays the statistics of distributed and returned questionnaires and their corresponding percentages. This is shown in table 2 below.

Table 2: Questionnaire Return Rate

\begin{tabular}{|l|c|c|c|}
\hline \multicolumn{1}{|c|}{ Ministry } & $\begin{array}{c}\text { Questionnaire } \\
\text { Distributed }\end{array}$ & $\begin{array}{c}\text { Questionnaire } \\
\text { Returned }\end{array}$ & $\begin{array}{c}\text { Questionnaire } \\
\text { Return Percentage } \\
(\%)\end{array}$ \\
\hline Federal Ministry of Agriculture & 51 & 47 & 92 \\
\hline Federal Ministry of Education & 113 & 101 & 89 \\
\hline Total & $\mathbf{1 6 4}$ & $\mathbf{1 4 8}$ & Average: $90.5 \%$ \\
\hline
\end{tabular}

Table 2 above reveals the number of questionnaires distributed to the sampled federal ministries and their corresponding return rate. It is crystal clear that the return rates are high and hence acceptable, having the highest return rate as $92 \%$, the lowest at $89 \%$ and the average return rate as $90.5 \%$.

Note: The return rate was calculated with the formula given as:

$Q R R=\frac{Q R}{Q D} \times \frac{100}{1}$

Where:

$\mathrm{QRR}=$ Questionnaire Return Rate

$\mathrm{QR}=$ Questionnaire Returned

QD = Questionnaire Distributed

\section{Analysis of the Returned Questionnaires}

The demographic characteristics of the respondents were carried out in this section with the application of tabled frequencies and percentages.

Table 3: Gender Distribution of the Respondents

\begin{tabular}{lll}
\hline Gender & Frequency & Percentage \\
\hline Male & 89 & 60 \\
Female & 59 & 40 \\
\hline Total & $\mathbf{1 4 8}$ & $\mathbf{1 0 0}$ \\
\hline
\end{tabular}

Source: Field Survey, 2022. 
Table 3 reveals that $60 \%$ of the respondents are male while $40 \%$ of the respondents are female. This implies that there are more male employees among the respondents than females in the selected ministries.

Table 4: Age Distribution of the Respondent

\begin{tabular}{lll}
\hline Age (In Years) & Frequency & Percentage \\
\hline $18-25$ & 25 & 17 \\
$26-35$ & 29 & 20 \\
$36-45$ & 78 & 53 \\
46 and above & 16 & 10 \\
\hline Total & $\mathbf{1 4 8}$ & $\mathbf{1 0 0}$ \\
\hline
\end{tabular}

Source: Field Survey, 2022.

It can be clearly seen that table 4 shows that 25(17\%) are between the ages of 18-25 years of age, $29(20 \%)$ of the respondents are between $26-35$ years of age, $53 \%$ corresponding to 78 respondents are between 36-45 years and 16(10\%) between the ages of 46 years or above. This implies that a greater number of the respondents are within the 36-45 years age bracket.

Table 5: Respondent Years of Working Experience

\begin{tabular}{lll}
\hline Working Experience & Frequency & Percentage \\
\hline $1-3$ & 11 & 7 \\
$4-6$ & 29 & 20 \\
6 years and above & 108 & 73 \\
\hline Total & $\mathbf{1 4 8}$ & $\mathbf{1 0 0}$ \\
\hline
\end{tabular}

Source: Field Survey, 2022.

Table 5 statistically shows that only $7 \%$ of the respondents (representing two persons) have 13 years of working experience. The table shows that $20 \%$ (representing 29 persons) have 4-6 years of working experience while $73 \%$ (representing 108 persons) have working experience that is 6 years and above. This information showed that the majority of the respondents have acquired good working experience and therefore should have a good knowledge of the study variables

Research Question One: To what extent has treasury single account affected fund misappropriation of selected Federal Ministries in Enugu State?

Table 6: The implementation of treasury single account has significantly improved adequate fund appropriation of selected Federal Ministries in Enugu State.

\begin{tabular}{lll}
\hline Item & Frequency & Percentage \\
\hline Strongly Disagree & 71 & 48 \\
Disagree & 48 & 32 \\
Undecided & 5 & 3 \\
Agree & 15 & 10 \\
Strongly Agree & 9 & 6 \\
\hline Total & $\mathbf{1 4 8}$ & $\mathbf{1 0 0}$ \\
\hline
\end{tabular}

Source: Field Survey, 2022. 
From table $6,7(48 \%)$ of the respondents strongly disagree that the implementation of treasury single account has significantly improved adequate fund appropriation of selected federal ministries in Enugu state, 48(32\%) disagree, 5(3\%) are undecided, 15(10\%) agree and 9(6\%) strongly agree. This entails on average that the majority of the respondents do not agree that the implementation of treasury single account has significantly improved adequate fund appropriation of selected Federal Ministries in Enugu State.

Table 7: The implementation of Treasury Single Account (TSA) has improved optimal fund disbursement

\begin{tabular}{lll}
\hline Item & Frequency & Percentage \\
\hline Strongly Disagree & 89 & 60 \\
Disagree & 29 & 20 \\
Undecided & 15 & 10 \\
Agree & 12 & 8 \\
Strongly Agree & 3 & 2 \\
\hline Total & $\mathbf{1 4 8}$ & $\mathbf{1 0 0}$ \\
\hline
\end{tabular}

Source: Field Survey, 2022.

Table 7 reveals that $89(60 \%)$ of the respondents strongly disagree that the implementation of treasury single account has improved optimal fund disbursement. $29(20 \%)$ disagree, $15(10 \%)$ are undecided, $12(8 \%)$ agree and $3(2 \%)$ strongly agree. This clearly shows that on average, the majority of the respondents do not agree that the implementation of treasury single account has improved optimal fund disbursement.

Table 8: The implementation of Treasury Single Account (TSA) has increased fund generation and proper utilization.

\begin{tabular}{lll}
\hline Item & Frequency & Percentage \\
\hline Strongly Disagree & 71 & 48 \\
Disagree & 48 & 32 \\
Undecided & 5 & 3 \\
Agree & 15 & 10 \\
Strongly Agree & 9 & 6 \\
\hline Total & $\mathbf{1 4 8}$ & $\mathbf{1 0 0}$ \\
\hline
\end{tabular}

Source: Field Survey, 2022.

From Table 8, 7 (48\%) of the respondents strongly disagree that the implementation of treasury single account has increased fund generation and proper utilization, $48(32 \%)$ disagree, $5(3 \%)$ are undecided, $15(10 \%)$ agree and $9(6 \%)$ strongly agree. This entails on average that the majority of the respondents do not agree that the implementation of treasury single account has increased fund generation and proper utilization.

Research Question Two: To what extent has treasury single account affected the prompt release of funds for goods and services of selected Federal Ministries in Enugu State? 
Table 9: The implementation of treasury single account has significantly reduced the bureaucracy involved in the release of funds for goods and services.

\begin{tabular}{lll}
\hline Item & Frequency & Percentage \\
\hline Strongly Disagree & 66 & 45 \\
Disagree & 59 & 40 \\
Undecided & 0 & 0 \\
Agree & 13 & 9 \\
Strongly Agree & 10 & 7 \\
\hline Total & $\mathbf{1 4 8}$ & $\mathbf{1 0 0}$
\end{tabular}

Source: Field Survey, 2022.

It can be clearly seen from table 9, 66(45\%) of the respondents strongly disagree that the implementation of treasury single account has significantly reduced the bureaucracy involved in the release of funds to sources, $59(40 \%)$ disagree, $13(9 \%)$ agree and $10(7 \%)$ strongly agree. This entails on average that the majority of the respondents are not in agreement that the implementation of treasury single account has significantly reduced the bureaucracy involved in the release of funds to sources.

Table 10: The implementation of Treasury Single Account (TSA) has improved the speed of efficiency of fund release for adequate implementation of prescribed functions

\begin{tabular}{lll}
\hline Item & Frequency & Percentage \\
\hline Strongly Disagree & 77 & 52 \\
Disagree & 49 & 33 \\
Undecided & 6 & 4 \\
Agree & 11 & 7 \\
Strongly Agree & 5 & 3 \\
\hline Total & $\mathbf{1 4 8}$ & $\mathbf{1 0 0}$ \\
\hline
\end{tabular}

Source: Field Survey, 2022.

Table 10 reveals that 77 (52\%) of the respondents strongly disagree that the implementation of treasury single account has improved speed of efficiency of fund release for adequate implementation of prescribed functions, 49 (33\%) disagree, $6(4 \%)$ are undecided, $11(7 \%)$ agree and $5(3 \%)$ strongly agree. This clearly shows that on average, the majority of the respondents agree that the implementation of treasury single account has improved the speed of efficiency of fund release for adequate implementation of prescribed functions.

Table 11: The implementation of the Treasury Single Account (TSA) has strengthened the relationship between fund generation and fund release for goods and services.

\begin{tabular}{lll}
\hline Item & Frequency & Percentage \\
\hline Strongly Disagree & 71 & 48 \\
Disagree & 48 & 32 \\
Undecided & 5 & 3 \\
Agree & 15 & 10 \\
Strongly Agree & 9 & 6 \\
\hline Total & $\mathbf{1 4 8}$ & $\mathbf{1 0 0}$ \\
\hline
\end{tabular}

Source: Field Survey, 2022. 
From Table 11, $71(48 \%)$ of the respondents strongly disagree that the implementation of treasury single account has strengthened the relationship between fund generation and fund release for sources, $48(32 \%)$ disagree, $5(3 \%)$ are undecided, $15(10 \%)$ agree and $9(6 \%)$ strongly agree. This entails on average that the majority of the respondents agree that the implementation of TSA has strengthened the relationship between fund generation and fund release for sources.

\section{Test of Hypotheses}

In this section, the hypotheses stated earlier in this research were tested using probability values anchored on the regression method. Three steps were used to test the hypotheses. In step one; the hypotheses were restated in null and alternate forms. In step two, the results were analyzed while in step three, decisions were made. The decision rule involved the rejection or acceptance of the null or alternate hypotheses based on the criterion of the techniques of analysis.

\section{Test of Hypothesis One}

$\mathbf{H}_{\mathbf{0 1}}$ : Treasury single account has not significantly ameliorated fund misappropriation in Federal Ministry of Agriculture and Ministry of Education in Enugu State.

$\mathbf{H}_{\mathbf{A 1}}$ : Treasury single account has significantly ameliorated fund misappropriation in Federal Ministry of Agriculture and Ministry of Education in Enugu State.

\section{Presentation and Analysis of Result}

Dependent Variable: Fund Misappropriation

Method: Least Squares

Date: 01/10/22 Time: 19:26

Sample: 148

Included observations: 148

\begin{tabular}{lrlll}
\hline \multicolumn{1}{c}{ Variable } & Coefficient & Std. Error & t-Statistic & Prob. \\
& & & & \\
\hline & & & & \\
TSA & 3.350808 & 3.400219 & 0.985468 & 0.3254 \\
& 0.621192 & 0.032170 & 19.30944 & 0.5567 \\
\hline & & & & \\
R-squared & 0.609384 & Mean dependent var & 20.72614 \\
Adjusted R-squared & 0.607750 & S.D. dependent var & 81.27694 \\
S.E. of regression & 50.90364 & Akaike info criterion & 10.70601 \\
Sum squared resid & 619292.2 & Schwarz criterion & 10.73493 \\
Log-likelihood & -1288.074 & Hannan-Quinn criter. & 10.71766 \\
F-statistic & 372.8547 & Durbin-Watson stat & 1.825809 \\
Prob(F-statistic) & 0.445874 & & \\
& & & \\
\hline
\end{tabular}

Source: Author's Computation Using E-views 
Model Line: FMISAP $=$ bo $+b_{1}$ TSA $+\mathrm{U}$

Regression Line: FMISAP $=3.350808+0.621192$ TSA

Where; FMISAP = Fund Misappropriation, TSA = Treasury Single Account and U = stochastic error term.

\section{Decision Rule}

The decision rule is to reject the null hypothesis $(\mathbf{H o})$ if the probability is less than 0.05 and to accept the null hypothesis (Ho) if the probability is greater than 0.05

\section{Decision}

From the above analysis, it is clearly seen that the probability value $=0.5567$ is greater than 0.05. This compels the acceptance of the null hypothesis (Ho) and the rejection of the alternative (Ha). Hence; treasury single account has no significant effect on fund misappropriation in selected federal ministries in Enugu State.

\section{Test of Hypothesis Two}

$\mathbf{H}_{\mathbf{0 2}}$ : Treasury single account has not significantly enhanced prompt release of funds for goods and services in Federal Ministry of Agriculture and Ministry of Education in Enugu State.

$\mathbf{H}_{\mathbf{A 1}}$ : Treasury single account has significantly enhanced prompt release of funds for goods and services in Federal Ministry of Agriculture and Ministry of Education in Enugu State.

\section{Step Two: Presentation and Analysis of Result}

Dependent Variable: PRF

Method: Least Squares

Date: 01/10/22 Time: 19:55

Sample: 148

Included observations: 148

\begin{tabular}{ccccc}
\hline Variable & Coefficient & Std. Error & t-Statistic & Prob. \\
& & & & \\
\hline C & 4.165906 & 3.381851 & 1.231842 & 0.2192 \\
TSA & 0.622225 & 0.032069 & 19.40296 & 0.8740
\end{tabular}

$\begin{array}{lrll}\text { R-squared } & 0.611682 & \text { Mean dependent var } & 21.01245 \\ \text { Adjusted R-squared } & 0.610057 & \text { S.D. dependent var } & 81.25610 \\ \text { S.E. of regression } & 50.74070 & \text { Akaike info criterion } & 10.69960 \\ \text { Sum squared resid } & 615333.7 & \text { Schwarz criterion } & 10.72852 \\ \text { Log-likelihood } & -1287.302 & \text { Hannan-Quinn criter. } & 10.71125 \\ \text { F-statistic } & 376.4749 & \text { Durbin-Watson stat } & 1.836720 \\ \text { Prob(F-statistic) } & 0.990231 & & \end{array}$

Source: Author's Computation Using E-views 
Model Line: $\mathrm{EP}=\mathrm{bo}+\mathrm{b}_{1} \mathrm{TSA}+\mathrm{U}$

Regression Line: $\mathrm{PRF}=4.165906+0.622225 \mathrm{TSA}$

Where PRF $=$ Prompt Release of Funds, TSA = Treasury Single Account and U = Stochastic Error Term.

\section{Decision Rule}

The decision rule is to reject the null hypothesis (Ho) if the probability is less than 0.05 and to accept the null hypothesis (Ho) if the probability is greater than 0.05 .

\section{Decision}

From the above analysis, it is clearly seen that the probability value $=0.8740$ is greater than 0.05. This compels the acceptance of the null hypothesis (Ho) and the rejection of the alternative (Ha). Hence; treasury single account has not significantly enhanced prompt release of funds for goods and services in selected federal ministries in Enugu State.

\section{CONCLUSION AND RECOMMENDATIONS}

There was enormous corruption prior to the implementation of the treasury single account, as evidenced by fund misappropriation, superfluous bureaucratic systems in fund distribution for agency uses, and other impediments. However, according to the findings of this study, the implementation of treasury single reduced fund misappropriation only little and did not considerably improve the fast flow of cash for sources. As a result, the TSA implementation policy increased public service performance, albeit not dramatically or strikingly. Based on the findings of the study, the following recommendations were articulated:

1. The adoption of TSA alone may not be sufficient to combat corruption in the Nigerian public sector, necessitating the strengthening of the country's judiciary, police, anti-graft agencies, and media to combat corruption and ensure transparency, probity, and timeliness in the handling of corruption-related cases.

2. To ensure the TSA policy's success, the federal government must show the political will to assure the policy's long-term viability, as well as tenaciously push TSA implementation by state and municipal governments across the country.

\section{REFERENCES}

Adegite, E. O. (2010). Accounting, Accountability and National Development. Nigerian Accountant, 43(1), 56-64.

Adeolu, A. (2015). Understanding The Treasury Single Account (TSA) System - Things You Should Know. Business \& Economy, Market Development. Bhatti.

Ahmed, A.I. (2016) The Treasury Single Account (TSA) as an Instrument of Financial Prudence and Management: Prospects and Problems. Research Journal of Finance and Accounting, ISSN 2222-1697, 7(4), 66-71. 
Akande, L. (2015), "Buhari orders Federal Ministries, Agencies to open Treasury Single Account", Press Release, August 9.

Akhidime, A.E. (2012) Accountability and Financial Reporting in Nigeria Public Financial Management: An Empirical Exploration. Journal of Accounting and Management Science, 7(6), 36-44.

Allison, P. \& Ndukwe. O.J (2021). Towards achieving public accountability in Nigeria public sectors: The role of treasury single account. International Journal of Academic Accounting, Finance \& Management Research (IJAAFMR). 5(1), 17-24.

Aminatu, M. (2016) The Impact of Integrated Financial Management System on Economic Development: The case of Ghana. M.A. Graduate School of International Studies, Korea University, Korea

Ariyo, A. (2005). Liquidity Management in Nigeria, Lagos, West African book publishers

Benjamin, E.O., Adanma, S.E. \& Jane, C.A (2020). Treasury single account implementation and financial performance of commercial banks in Nigeria. European Journal of Business and Management Research. 5(6), 112-118.

Bhunia, A. (2010). A trend analysis of liquidity management efficiency in selected private sector industry, Indian steel; International Journal of Research in Commerce and Management, 1(5); 9-21

CBN (2015) Revised Guidelines for compliance with Treasury Single Account by Banks in Nigeria

Chukwu, J. (2020). The implementation of the TSA and the likely outcomes. Lagos: John Wiley \& Sons, Inc

Eljelly, A. (2004). Liquidity-Profitability Tradeoff: An Empirical Investigation in an Emerging Market. International Journal of Commerce \& Management. 14(2), pp. 48-61.

Eme, O. I., Chukwurah, D.C., \& Emmanuel, N.I., (2015). An Analysis Of Pros And Cons Treasury Single Account Policy In Nigeria Arabian Journal of Business and Management Review (OMAN Chapter) 5(4)

Eze, O. (2020). The re-emergence of TSA in public resource management in Nigeria. ThisDay, January 15, p, 26.

Finance, Planning and Economic Development

Guardian Editorial,(2015). Buhari on Treasury Single Account, Guardian, retrieved on August 28, P16.

Gwarzo. M. (2016)., TSA: Weep Not SEC. Thisdaylive http://www.thisdaylive.com/index.php/2016/03/09/tsa-weep-not-sec/ retrieved March 2016

Ibrahim. J1., Odunayo, K.O. \& Tijani O. F (2019). Treasury single account as an antidote to corruption in Nigeria. International Journal of Innovative Finance and Economics Research 7(2):43-50

IMF (2010). Treasury Single Account: Concept, Design and Implementation Issues. Working paper prepared by Sailendra Pattanayak and Israel Fainboim, Authorized for distribution by Marco Cangiano and Michel Lazare

Iroegbu, C (2015)," Treasury Single Account'1l block leakages', Vanguard, August 24, P38

John A.I., Amos, I.G., Alematu, A. \& Patience, O.O (2021). Effect of treasury single account on corruption in the Nigerian public sector. International Journal of Academic Research in Business and Social Sciences. 8(12), 47-56.

Kanu. C. (2016), Impact of Treasury Single Account on the Liquidity.ABC Journal of Advanced Research, 5(1) 43-52. 
Lienert (2009). Modernizing Cash Management, Technical Notes and Manuals, Fiscal Affairs Department (Washington: International Monetary Fund).

Lodikero, O. F., Michael, O., and Olateru, O. A. (2018). Treasury Single Account: A Tool for Accountability and Transparency in Ondo State, Nigeria International Journal of Economics, Commerce and Management United Kingdom. 9(12), 121-124.

Mathias Okwe, Abuja. Chijioke Nelson, Temiloluwa Adeoye, David Ogah (2015), Treasury Single Account: Giving Life to Jonathan's 'Dead' Policy Directives', Sunday Guardian, retrieved August 16, Pp52-58

Muhakanizi (2014). Strengthening Public Financial Management and Accountability Ministry of

Nwankwo, G. (2004). Bank Management Principles and Practice, Lagos. Malt House PressLimited

Obinna, C. (2015). Banks Face Liquidity Strain as FG Fully Enforces Treasury Single Account, Thisday Monday, 11 August, P52

Olagunju, A. Adeyanju, O. and Olabode, O. (2011). Liquidity Management and Commercial Bank's Profitability in Nigeria. Research Journal of Finance and Accounting. Vol. 2, No. 7/8.

Raheman, A. and Nasir, M. (2007). Working Capital Management and Profitability - Case of Pakistani Firm. International Review of Business Research Papers, 3(1), 279-300

Sabo, A., Muhammad, S. \& KA ${ }^{\text {ce }}$ OJE, M. R (2019). The impact of treasury single account on bank liquidity: Fresh evidence from Nigeria East African Scholars. Journal of Economics, Business and Management 2(5).

Solanke, A. A. (2018). Opinion and perception of treasury single account implementation: implications for revenue generation and utilisation in Nigeria. European Scientific Journal, 14(1), 1-12.

Vanguard Editorial (2015). Treasury Single Account: Bank deposits loss may hit N2trn, August 17, P 18 